\title{
(LIBRARY RESEARCH) PERANAN PENGEMBANGAN MANAJEMEN KINERJA TENAGA ADMINISTRASI KESEHATAN TERHADAP PENINGKATAN MUTU PELAYANAN KESEHATAN DI PUSKESMAS
}

\section{THE ROLE OF DEVELOPMENT OF PERFORMANCE MANAGEMENT OF HEALTH ADMINISTRATION ON IMPROVING THE QUALITY OF HEALTH SERVICES IN COMMUNITY HEALTH CENTERS}

\author{
Aris Dwi Cahyono \\ STIKes Pamenang \\ Korespondensi Penulis: arisdc81@gmail.com; +6281359124077
}

\begin{abstract}
Abstrak
Penelitian kepustakaan ini bertujuan untuk menyusun dan mendeskripsikan Peranan Pengembangan Manajemen Kinerja Tenaga Administrasi Kesehatan Terhadap Peningkatan Mutu Pelayanan Kesehatan di Puskesmas. Metode yang digunakan adalah metode penelitian kepustakaan. Metode pengumpulan data yang digunakan yakni metode dokumentasi. Teknik analisis data yang digunakan adalah analisis isi. Untuk menjaga ketepatan pengkajian dan mencegah kesalahan informasi dalam analisis data maka dilakukan pengecekan antar pustaka dan membaca ulang pustaka serta memperhatikan komentar reviewer. Hasil studi ini adalah menunjukkan bahwa semakin baiknya peran pengembangan manajemen kinerja tenaga kesehatan termasuk tenaga adminisrasi kesehatan maka secara signifikan dapat meningkatkan mutu pelayanan kesehatan di puskesmas. Mutu adalah ukuran yang dibuat oleh konsumen terhadap produk atau jasa yang dilihat dari segala dimensi atau karakteristik untuk memenuhi tuntutan kebutuhan, keamanan, dan kenyamanan konsumen. Pelayanan kesehatan yang bermutu adalah pelayanan kesehatan yang dapat memuaskan setiap pemakai jasa pelayanan kesehatan sesuai tingkat kepuasan rata-rata penduduk. Penyelenggaraannya juga harus sesuai dengan standar dan kode etik profesi yang telah ditetapkan.
\end{abstract}

Kata Kunci: Manajemen Kinerja, Mutu Pelayanan Kesehatan, Puskesmas.

\begin{abstract}
Abstrak
This library research aims to compile and describe the Role of Health Administration Personnel Performance Management Development to Improve the Quality of Health Services at the Puskesmas. The method used is library research method. The data collection method used is the documentation method. The data analysis technique used is content analysis. To maintain the accuracy of the assessment and prevent misinformation in data analysis, inter-library checks and re-reading of the literature as well as attention to reviewers' comments are carried out. The results of this study indicate that the better the role of developing the performance management of health workers, including health administrative personnel, can significantly improve the quality of health services at the puskesmas. Quality is a measure made by consumers of products or services that are seen from all dimensions or characteristics to meet the demands of consumer needs, safety, and comfort. Quality health services are health services that can satisfy every user of health services according to the level of satisfaction of the average population. The implementation must also be in accordance with the standards and professional code of ethics that have been set.
\end{abstract}

Keywords: Performance Management, Quality of Health Services, Puskesmas.

Submit / unggah : 11 Oktober 2021, Accepted : 6 Desember 2021

Website : jurnal.stikespamenang.ac.di | Email : jurnal.pamenang@gmail.com 


\section{Pendahuluan}

Kesehatan merupakan kebutuhan dasar masyarakat. Setiap negara, baik negara maju dan negara berkembang mengakui bahwa tingkat kesehatan menunjukan tingkat kesejahteraan suatu bangsa, karena tingkat kesehatan memiliki keterkaitan dengan tingkat kemiskinan. Sedangkan tingkat kemiskinan juga terkait dengan tingkat kesejahteraan. Oleh karena kesehatan merupakan faktor utama kesejahteraan masyarakat maka kesehatan sudah seharusnya menjadi perhatian utama pemerintah pusat maupun daerah sebagai penyelenggara pelayanan publik. Dalam penyelenggaraan pelayanan publik masih dijumpai beberapa kekurangan, dan bila dilihat dari segi kualitas masih jauh dari harapan masyarakat. Hal ini ditunjukkan dengan masih munculnya berbagai keluhan masyarakat melalui media massa. Pemerintah secara hakiki ingin memberikan pelayanan publik yang terbaik, mengingat fungsi utama pemerintah adalah melayani masyarakat.

Masyarakat secara ideal ingin mendapatkan pelayanan publik yang terbaik dari permerintah. Tetapi pada kenyataannya pemerintah begitu sedikit memberikan pelayanan yang berkualitas dan memuaskan. Di sisi lain, masyarakat sering kali menerima pelayanan yang buruk dari pemerintah. Kesenjangan atau ketidakcocokan antara peraturan / idealnya dengan kenyataan/fakta yang terjadi dilapangan inilah yang membuat mengapa masalah kualitas pelayanan publik masih menjadi bahan perbincangan yang menarik. Salah satu wujud komitmen pemerintah terhadap pelayanan kesehatan masyarakat adalah dengan dibentuknya puskesmas sebagai pelayanan publik dibidang kesehatan. Puskesmas adalah Unit Pelaksana Teknis Dinas Kesehatan Kota / Kabupaten (UPTD) yang bertanggungjawab dalam penyelenggaraan kesehatan disuatu wilayah.

Puskesmas merupakan unit pelaksana tingkat pertama serta menjadi ujung tombak pembangunan kesehatan. Sebagai pusat pelayanan kesehatan tingkat pertama, puskesmas wajib menyelenggarakan pelayanan kesehatan secara bermutu, adil dan merata. Pelayanan yang diselenggarakan adalah pelayanan kesehatan dasar yang dibutuhkan sebagian besar masyarakat dan sangat strategis dalam upaya meningkatkan status kesehatan masyarakat umum.
Pemberian pelayanan secara cepat dan tepat dalam era reformasi dan globalisasi yang sedemikian pesat dan cepat, mutlak dilaksanakan, sebab kalau tidak akan menimbulkan gejolak sosial. Begitu juga halnya mengenai pelayanan di rumah sakit. Pelayanan kesehatan yang belum sesuai dengan harapan pasien, maka diharapkan menjadi suatu masukan bagi organisasi layanan kesehatan agar berupaya meningkatkan pelayanannya. Jika pelayanan kesehatan yang diperoleh pasien pada suatu fasilitas pelayanan kesehatan sesuai dengan harapannya, masyarakat atau pasien pasti akan selalu datang berobat ke fasilitas pelayanan kesehatan tersebut.

Pelayanan adalah semua upaya yang dilakukan karyawan untuk memenuhi keinginan pelanggannya dengan jasa yang akan diberikan. Menurut Zeithaml, Parasuraman dan Berry (dalam Tjiptono, 1997) terdapat lima dimensi pokok yang berkaitan dengan kualitas jasa yang dikenal dengan teori Service Quality yaitu tangibles, reliability, responsiveness, assurance, dan empathy. Keunggulan layanan tidak akan terwujud jika ada salah satu prinsip pelayanan ada yang dianggap lemah.

Pasien mengartikan pelayanan yang bermutu dan efektif adalah jika pelayanannya nyaman, menyenangkan, dan petugasnya ramah yang mana secara keseluruhan memberikan kesan kepuasan terhadap pasien. Sedangkan dari pihak pemberi pelayanan mengartikan pelayanan yang bermutu dan efisien jika pelayanannya sesuai dengan standar pemerintah. Adapun kondisi yang sering dikeluhkan oleh pemakai jasa rumah sakit adalah: sikap dan tindakan dokter atau perawat, sikap petugas administrasi, sarana yang kurang memadai, lambannya pelayanan, persediaan obat, tarif pelayanan, peralatan medis dan lain-lain.

\section{Metode}

Pada rancangan ini menggunakan jenis/pendekatan penelitian yang berupa Studi Kepustakaan (Library Research). Studi kepustakaan merupakan suatu studi yang digunakan dalam mengumpulkan informasi dan data dengan bantuan berbagai macam material yang ada di perpustakaan seperti dokumen, buku, majalah, kisah-kisah sejarah, dsb (Mardalis, 1999 dalam Mirzaqon, 2017). 
Studi kepustakaan juga dapat mempelajari beberbagai buku referensi serta hasil penelitian sebelumnya yang sejenis yang berguna untuk mendapatkan landasan teori mengenai masalah yang akan diteliti (Sarwono, 2006 dalam Mirzaqon, 2017). Studi kepustakaan juga berarti teknik pengumpulan data dengan melakukan penelaahan terhadap buku, literatur, catatan, serta berbagai laporan yang berkaitan dengan masalah yang ingin dipecahkan (Nazir, 1988 dalam Mirzaqon, 2017). Sedangkan menurut ahli lain studi kepustakaan merupakan kajian teoritis, referensi serta literatur ilmiah lainnya yang berkaitan dengan budaya, nilai dan norma yang berkembang pada situasi sosial yang diteliti (Sugiyono, 2012 dalam Mirzaqon, 2017). Penelitian ini merupakan jenis riset kepustakaan (library research).

Dalam penelitian ini penulis menerapkan metode penelitian kepustakaan karena setidaknya ada beberapa alasan yang mendasarinya. Pertama bahwa sumber data tidak melulu bisa didapat dari lapangan. Adakalanya sumber data hanya bisa didapat dari perpustakaan atau dokumen-dokumen lain dalam bentuk tulisan, baik dari jornal, buku maupun literatur yang lain. Kedua, studi kepustakaan diperlukan sebagai salah satu cara untuk memahami gejala-gejala baru yang terjadi yang belum dapat dipahami, kemudian dengan studi kepustakaan ini akan dapat dipahami gejala tersebut. Sehingga dalam mengatasi suatu gejala yang terjadi, penulis dapat merumuskan konsep untuk menyelasaikan suatu permasalahan yang muncul. Alasan ketiga ialah data pustaka tetap andal untuk menjawab persoalan penelitinya. Bagaimanapun, informasi atau data empirik yang telah dikumpulkan oleh orang lain, baik berupa buku-buku, laporan-laporan ilmiah ataupun laporan-laporan hasil penelitian tetap dapat digunakan oleh peneliti kepustakaan. Bahkan dalam kasus tertentu data lapangan masih kurang signifikan untuk menjawab pertanyaan penelitian yang akan dilaksanakan.

\section{Tahap-Tahap Kepustakaan}

Penelitian

Adapun tahap-tahap yang harus ditempuh penulis dalam penelitian kepustakaan adalah sebagai berikut:
a. Mengumpulkan
bahan-bahan penelitian. Karena dalam penelitian ini adalah penelitian kepustakaan, maka bahan yang dikumpulkan adalah berupa informasi atau data empirik yang bersumber dari buku-buku, jurnal, hasil laporan penelitian resmi maupun ilmiah dan literatur lain yang mendukung tema penelitian ini.

b. Membaca bahan kepustakaan. Kegiatan membaca untuk tujuan penelitian bukanlah pekerjaan yang pasif. Pembaca diminta untuk menyerap begitu saja semua informasi "pengetahuan" dalam bahan bacaan melainkan sebuah kegiatan 'perburuan' yang menuntut keterlibatan pembaca secara aktif dan kritis agar bisa memperoleh hasil maksimal. Dalam membaca bahan penelitian, pembaca harus menggali secara mendalam bahan bacaan yang memungkinkan akan menemukan ideide baru yang terkait dengan judul penelitian.

c. Membuat catatan penelitian. Kegiatan mencatat bahan penelitian boleh dikatakan tahap yang paling penting dan barang kali juga merupakan puncak yang paling berat dari keseluruhan rangkaian penlitian kepustakaan. Kerena pada akhirnya seluruh bahan yang telah dibaca harus ditarik sebuah kesimpulan dalam bentuk laporan.

d. Mengolah catatan penelitian. Semua bahan yang telah dibaca kemudian diolah atau dianalisis untuk mendapatkan suatu kesimpulan yang disusun dalam bentuk laporan penelitian.

\section{Pendekatan Penelitian}

Penelitian ini menggunakan pendekatan kualitatif. Sebab sumber data maupun hasil penelitian dalam penelitian kepustakaan (library research) berupa deskripsi kata-kata. Moleong mengungkapkan sebelas karakteristik penelitian kualitatif, yaitu: berlatar alamiah, manusia sebagai alat (instrumen), menggunakan metode kualitatif, analisa data secara induktif, teori dari dasar/grounded theory (menuju pada arah penyusunan teori berdasarkan data), data 
bersifat deskriptif (data yang dikumpulkan berupa kata-kata, gambar dan bukan angkaangka), lebih mementingkan proses dari pada hasil, adanya batas yang ditentukan oleh fokus, adanya kriteria khusus untuk keabsahan data, dan desain yang bersifat sementara (desain penelitian terus berkembang sesuai dengan kenyataan lapangan), hasil penelitiaan dirundingkan dan disepakati bersama (hasil penelitian dirundingkan dan disepakati bersama antar peneliti dengan sumber data). Dari kutipan ini dapat dipahami bahwa penulis menekankan akan pentingnya proses dalam penelitian dibandingkan hasilnya. Secara umum pendekatan penelitian kualitatif pada studi kepustakaan sama dengan penelitian kualitatif yang lain. Yang menjadi perbedaan hanyalah sumber data atau informasi yang dijadikan sebagai bahan penlitian.

Metode kualitatif digunakan untuk mendapatkan data yang mendalam, suatu data yang mengandung makna. Penulis dalam penelitian ini akan menggali makna dari informasi atau data empirik yang didapat dari buku-buku, hasil laporan penelitian ilmiah atau pun resmi maupun dari literatur yang lain.

\section{Sumber Data}

Penelitian ini merupakan jenis penelitian kepustakaan atau library research. Maka sumber data bersifat kepustakaan atau berasal dari berbagai literatur, di antaranya buku, jurnal, surat kabar, dokumen pribadi dan lain sebagainya. Untuk lebih jelasnya, maka sumber data dalam penelitian ini dibedakan menjadi sumber primer dan sumber sekunder, dengan uraian sebagai berikut:

\section{A. Sumber Primer}

Sumber primer adalah sumber data pokok yang langsung dikumpulkan peneliti dari objek penelitian. Adapun sumber primer dalam penelitian ini adalah buku yang menjadi objek dalam penelitian ini.

\section{B. Sumber Data Sekunder}

Sumber sekunder adalah sumber data tambahan yang menurut peneliti menunjang data pokok. Adapun sumber sekunder pada penelitian ini adalah bukubuku lain yang mengkaji tentang konsep pendidikan berbasis pengalaman. Bukubuku yang masuk sebagai sumber sekunder dijadikan sebagai pendukung data primer.
Artinya buku ini berposisi sebagai pendukung buku primer untuk menguatkan konsep pendidikan berbasis pengalaman yang ada di dalam buku primer.

\section{Teknik Pengumpulan Data}

Teknik pengumpulan data berkaitan dengan sumber data. Teknik pengumpulan data yaitu berupa cara yang digunakan oleh peneliti untuk mengumpulkan dan menggali data yang bersumber dari sumber data primer dan sumber data sekunder. Oleh karena sumber data berupa data- data tertulis, maka teknik pengumpulan data dalam penelitian ini menggunakan teknik dokumentasi.

Dokumentasi berasal dari kata dokumen yang berarti catatan peristiwa yang sudah berlalu yang bisa berbentuk tulisan, gambar atau karya-karya monumental dari seseorang. Atau dengan kata lain, dokumen adalah tulisan, gambar atau karya-karya yang monumental yang berisi suatu ide tertentu. Atau gampangnya adalah suatu pikiran atau gagasan yang dituangkan dalam bentuk tulisan, gambar maupun dalam bentuk karya yang lain.

Kemudian, teknik dokumentasi adalah suatu cara yang dilakukan dengan mencari data mengenai hal-hal atau variabel yang berupa catatan, transkip, buku, surat kabar, majalah, prasasti, notulen rapat, leger, agenda, dan sebagainya. Teknik dokumentasi berarti cara menggali dan menuangkan suatu pemikiran, ide atau pun gagasan dalam bentuk tulisan atau dalam bentuk gambar maupun karya-karya yang lain.

Penulis menggunakan teknik
pengumpulan data dengan cara dokumentasi karena jenis penelitian ini adalah penelitian kepustakaan. Penelitian kepustakaan adalah penelitian yang sumber data empirik yang primer maupun sekunder berasal dari buku-buku, dokumen-dokumen, jurnal, atau literaturliteratur yang lain.

\section{Teknik Analisis Data}

Teknik analisis data yang penulis gunakan diantaranya adalah sebagai berikut:

\begin{tabular}{lllr} 
a. Analisis Konten & & \\
Analisis & konten & (content \\
analysis) atau & kajian isi & adalah \\
\hline
\end{tabular}


metodologi penelitian yang memanfaatkan seperangkat prosedur untuk menarik kesimpulan yang sahih dari sebuah buku atau dokumen. Sementara Harold D. Lasswell menyatakan bahwa analisis konten (content analysis) adalah penelitian yang bersifat pembahasan mendalam terhadap isi suatu informasi tertulis atau tercetak dalam media massa. Dari penjelasan di atas dapat disimpulkan bahwa analisis konten adalah suatu cara penelitian dengan tahapan tertentu untuk mengambil inti dari suatu gagasan maupun informasi yang kemudian ditarik sebuah kesimpulan. Penulis menggunakan teknik analisis data berupa analisis konten (content analysis) karena jenis penelitian ini adalah jenis penelitian kepustakaan, di mana sumber datanya adalah berupa buku dan dokumendokumen maupun literatur dalam bentuk yang lain.

\section{b. Analisis Induktif}

Analisis data dalam penelitian dengan pendekatan kualitatif bersifat induktif, yaitu suatu analisis berdasarkan data yang diperoleh, selanjutnya dikembangkan pola hubungan tertentu atau menjadi hipotesis, selanjutnya dicarikan data lagi secara berulang-ulang hingga hipotesis diterima dan hipotesis tersebut berkembang menjadi teori.

\section{c. Deskriptif Analitik}

Metode deskriptif analitik adalah metode dengan cara menguraikan sekaligus menganalisis. Dengan menggunakan kedua cara secara bersama-sama maka diharapkan objek dapat diberikan makna secara maksimal.

\section{Hasil Penelitian}

A. Penelitian Saputra (dipublikasikan tahun 2016) tentang Analisis Kinerja Tenaga Medis Puskesmas Kecamatan Kampar Utara Kabupaten Kampar. Hasil penelitian diperoleh:

1. Kinerja para tenaga medis di puskesmas Kampar Utara belum maksimal, berdasarkan hasil wawancara yang peneliti lakukan pada pasien, warga, maupun pihak keluarga. Berdasarkan indikator yang di kemukakan oleh Anwar Prabu Mangkunegara pada kategori kualitas dan kualitas puskesmas kecamatan Kampar Utara masih belum tercapai. Sedangkan pada kategori tanggung jawab dan pelaksanaan tugaspuskesmas kecamatan Kampar Utara sudah tercapai. Maka secara keseluruhan kinerja para tenga medis puskesmas kecamatan Kampar Utara belum maksimal karena masih terdapat kekurangan dan tidak berjalan sesuai dangan Standar Operasioanal Prosedur ( SOP ) yang telah ditetapkan.

2. Faktor yang mempengaruhi kinerja tenaga medis di puskesmas kecamatan Kampar Utara adalah Kurangnya kesadaran pihak penyelenggara pelayanan khususnya bagi tenaga medis puskesmas kecamatan Kampar Utara dalam menjalankan tugas. Kedisiplinan para tenaga medis dalam menjalankan tugas, serta masih terbatasnya Sarana dan prasarana di puskesmas kecamatan Kampar Utara, dimana semakin lengkap sarana dan prasarana yang dimiliki maka akan semakin baik kinerja para tenaga medis dalam melayani pasien.

B. Penelitian Aisyah (dipublikasikan tahun 2016) tentang Penilaian Kinerja Pegawai Puskesmas Rowosari, Kecamatan Tembalang, Semarang. Hasil penelitian menunjukkan:

1. Input penilaian kinerja pegawai Puskesmas Rowosari yang terdiri dari ruang lingkup penilaian kinerja $(5 \mathrm{~W}+1 \mathrm{H})$ telah mengacu pada teori manajemen.

a. What : kuantitas kerja, kualitas kerja, ketepatan waktu, kedisiplinan, kerjasama, orientasi terhadap pelayanan, loyalitas, komitmen, dan integritas

b. Why : mengetahui capaian kerja pegawai, orientasi pelayanan, sarana untuk petimbangan perbaikan, sarana pengambilan keputusan.

c. Where : di dalam Puskesmas Rowosari pada saat jam kerja. 
d. When : secara periodik dan terusmenerus

e. Who : Kepala Puskesmas Rowosari untuk pegawai fungsional, Kasubag Tata Usaha Puskesmas Rowosari untuk staff Tata Usaha

f. How : Modern menggunakan Management by Objective (MBO), titik acuan penilaian pada hasil dan perilaku kerja dengan sistem kompensasi.

2. Proses masih belum terlalu baik, penjelasan singkat yang lebih baik dilakukan secara personal hanya dilakukan secara serentak melalui seminar pegawai. Pun dengan pelatihan, pelatihan untuk pegawai terkait dengan sistem penilaian kinerja pegawai belum dilakukan. Pelatihan hanya diperuntukan bagi pegawai penilai seperti Kepala Puskesmas dan Kasubag Tata Usaha.

3. Output sistem penilaian kinerja pegawai yang berorientasi pada kompensasi dan capaian kerja cukup berhasil membuat pegawai lebih disiplin dan termotivasi untuk berkinerja.

4. Hambatan dalam pelaksanaan penilaian kinerja di Puskesmas Rowosari adalah hambatan sarana prasarana, hambatan hukum, hallo effect, dan kurangnya komunikasi.

B. Penelitian (Library Research) Husaini (dipublikasikan tahun 2017), tentang Peranan Manajemen Sumberdaya Manusia Dalam Organisasi. Hasil adalah sebagai berikut:

Pentingnya MSDM ini dapat disoroti dari berbagai perspektif. S.P. Siagian menyoroti relevansi dan pentingnya MSDM dari enam prespektif yaitu perspektif politik, ekonomi, sosialkultural, hukum, administrasi dan teknoligi.

1. Perspektif Politik.

Pentingnya MSDM pada perspektif ini lebih banyak mengarah pada sudut makro, bahwa sumber daya manusia merupakan asset yang penting yang dimiliki oleh suatu organisasi mulai dari level makro (Negara), bahkan internasional, hingga level mikro. Sumber day amanusia ynag terdidik, trampil, cakap, disiplin, tekun, kreatif, idealis, mau bekerja keras, kuat fisik/mental, setyia pada cita-cita dan tujuan organisasi, akan sangat berpengaruh positif pada keberhasilan dan kemajuan organisasi. Jadi sumber dya manusia memegang peranan sentral dan paling menentukan. Tanpa MSDM yang handal pengolahan, penggunaan dan pemanfaatan sumber-sumber lainnya itu akan menjadi tidak efektif, efisien dan produktif.

2. Perspektif Ekonomi

Dari perspektif ekonomi orang sering beranggapan bahwa pemahaman MSDM tidak lainkarena untuk kepentingan ekonomi semata-mata. Anggapan yang demikian dijustifikasikan oleh kenyataan bahwa manusia sering dipandang sebagai salah satu factor produksi untuk menghasilkan barang dan jasa oleh satuan-satuan ekonomi. Manusia tidak bias diasamakan dengan begitu saja dengan mesin, peralatan, modal, metode dan pasar. Hal seperti tersebut merupakan tindakan yang mengingkari kenyataan bahwa manusia sebagai makhluk yang dinamis, penuh cinta, rasa, dan karsa. Jadi manusia adlah pusat segalanya bagi suatu organisasi. Manusia bisa menjadi pusat persoalan organisasi manakala tidak dikembangkan dan tidak ditingkatkan potensi-potensinya. Sebaliknya manusia merupakan pusat segala keberhasilan organisasi manakala segala dayanya dikembangkan secara wajar dan meyakinkan.

3. Perspektif Hukum

Dalam organisasi terdapat berbagai peraturan, ketentuan, atu perjanjian yang kesemuanya dasarnya mengatur tentang hak dan kewajiban secara timbal balik antar organisasi dengan anggotanya, antara orang yang memperkerjakan dengan orang yang dipekerjakan. Pemeliharaan keseimbangan tersebut menuntut 
adanya kejelasan mengenai hak dan kewajiban itu sendiri dari masingmasing pihak dalam organisasi. Semua itu bisa menjadi jelas dan bisa diwujudkan hanya melalui suatu sistem amnajemen yang tepat. MSDM yang dikelola secara tepat dan teratur merupakan alternative yang paling relevan.

4. Perspektif Sosial Kultural

Ada dua alasan utama yang mendasari perspektif ini yaitu:

Pertama, sisi yang satu ini lebih peka karena berkaitan langsung harkat dan martabat manusia. Kesempatan berkarya merupakan upaya untuk meningkatkan harkat dan martabatnya. Harkat dan martabat tidak bisa diukur dengan hal-hal yang bersifat kebendaan tetapi juga non fisisk, diman bekerja tidak hanya untuk memenuhi kebutuhan fisik saja melainkan juga untuk diwujudkannya kebutuhan sosiopsikologis.

Kedua, ditekankan bahwa sulit diperoleh suatu system MSDM yang bebas nilai. Pemenuhan kebutuhan sosio-psikologis teriakt pada normanorma sosial yang berlaku didalam masyarakat dimana ornag itu menjadi bagian. Nilai-nilai itulah yang akan menentukan baik-buruknya,wajartidaknya, dan sekaligus menjadi barometer penilaian bagi seseorang.

5. Perspektif Administrasi

Perspektif ini menekankan bhawa peranan organisasi pada jama modern ini menjadi semakin penting. Manusia moder sekarang lebih mengenal pameo manusia organisasional. Tanpa organisasi tanap bantuan orang lain tiadk akan bisa mewujudkan impiannya. Ketergantungan kepada orang lain inilah yang mendorong manusia untuk berorganisasi. Ini mengindikasikan bahwa maju atau mundurnya kehidupan manusia tergantung pada kemampuannya untuk mengatur dan memanfaatkan sumber daya yang ada pada organisasi. Disinilah letak relevansi dan pentingnya MSDM.
6. Perspektif Teknologi

Relevansi dan pentingnya MSDM tidak terlepas dari berbagi perkembangan dan kemajuan yang dicapai dibidang IPTEK. Manusia diharapkan agar dapat menyesuaikan diri dengan berbagai perkembangan terbut. Untuk itu manusia perlu berbekal kemampuan, kecakapan, ketrampilna yang sesuai. Hal ini hanya bisa dicapai melalui suatu system manjemen sumber daya manusia yang tepat. (Faustino, 2003).

C. Penelitian Indrayathi (dipublikasikan tahun 2014) tentang Mutu Pelayanan Puskesmas Perawatan yang Berstatus Badan Layanan Umum Daerah. Hasil penelitian menunjukkan sebagai berikut:

1. Persepsi Masyarakat Pengguna Layanan Puskesmas

Persepsi masyarakat pengguna layanan puskesmas perawatan yang telah berstatus BLUD mengenai kualitas layanan berbagai puskesmas, yaitu Puskesmas Ubud I (34 orang), Puskesmas Payangan (13 orang), Puskesmas Tampaksiring II (33 orang), dan Puskesmas Tegallalang I (25 orang). Menunjukkan bahwa persepsi masyarakat pengguna layanan pada Puskesmas Ubud I mengenai kelima dimensi mutu termasuk dalam kategori kurang baik. Pada Puskesmas Payangan dan Puskesmas Tampaksiring II, persepsi masyarakat menyatakan dimensi mutu reliability, assurance, dan empathy baik. Sedangkan, pada Puskesmas Tegallalang I persepsi masyarakat yang menyatakan baik hanya pada dimensi reliability. Persepsi pengguna layanan puskesmas perawatan yang berstatus BLUD di Kabupaten Gianyar diukur dengan menggunakan kuesioner yang mengacu kepada lima dimensi mutu pelayanan kesehatan yaitu keandalan (reliability), cepat tanggap (reponsiveness), kepastian (assurance), empati (emphaty) dan bukti langsung (tangible). Hasil survei tingkat kepuasan pengguna secara keseluruhan mengenai layanan puskesmas perawatan ada empat dimensi mutu yang dinilai dalam kategori persepsi 
"kurang baik" yakni untuk dimensi bukti langsung, dimensi kesigapan, dimensi kepercayaan, dan dimensi perhatian. Sedangkan, dimensi yang memiliki persepsi "baik" yaitu hanya dimensi kehandalan.

2. Persepsi Pemberi Pelayanan Kesehatan Kebijakan BLUD Puskesmas di Kabupaten Gianyar telah ditetapkan sejak bulan Januari tahun 2010. Dari 13 puskesmas yang telah berstatus BLUD, terdapat empat puskesmas yang merupakan puskesmas perawatan dengan menyediakan pelayanan 24 jam. Dalam praktiknya, sebagian besar responden berpendapat bahwa kebijakan BLUD puskesmas memberikan keleluasaan bagi puskesmas untuk melaksanakan program-program yang tepat sasaran sesuai dengan kebutuhan puskesmas. Baik dari pihak manajemen puskesmas dan staf puskesmas sangat terbantu dengan adanya kebijakan BLUD puskesmas. Seperti terangkum dalam kutipan wawancara berikut:

"Kebijakan (Puskesmas BLU) ini memudahkan kami dalam melakukan inovasi dalam memberikan pelayanan" (Informan 5)

"Bagus bu...target program bisa lebih tercapai...saya di ANC seneng sekali karena program yang sudah direncanakan bisa dilakukan" (Informan 9)

"Kebutuhan itu, kayak obat itu e..kita bisa merencanakan sesuai dengan kebutuhan kita sendiri dan belanja apa gitu kita juga sendiri, kalau dulu sebelum BLUD kan dibuat dari dinas kesehatan, apa yang dibeli disana kita terima yang itu, tidak sesuai dengan kebutuhan kita" (Informan 3)

Meskipun kebijakan BLUD ini sangat baik, namun implementasi kebijakan BLUD sangat susah. Dalam hal ini, diperlukan kerja keras seluruh tim puskesmas sehingga pelaksanaan kebijakan tersebut berjalan lancar. Banyak permasalahan yang muncul di awal pelaksanaan BLUD. Hambatan terbesar yang dialami oleh pelaksana kebijakan ini adalah kurangnya tenaga yang kompeten sesuai dengan syarat dan ketentuan BLUD.

"Susah sekali awalnya..kami tidak punya kapasitas untuk membuat laporan keuangan dan administrasi yang susah.." (Informan 7)
"Banyak sekali dulu, itu dah yang saya bilang awal dari kita masuk BLU itu karena..yang..yang..banyak berubah kan manajemen itu, administrasi dan manajemen, memang susah..susah tapi karena kita ee..barengan bertiga belas jadi kan samasama gitu lo cari informasi" (Informan 1)

"Banyak masalah dalam proses implementasinya..kami belajar ke pemda bagian keuangan karena dinas juga belum punya pengalaman tentang BLU" (Informan 8)

Selain ada beberapa permasalahan pada awal pelaksanaan kebijakan BLUD, terdapat pula beberapa hambatan terkait pelaksanaan puskesmas perawatan yang menyediakan pelayanan 24 jam. Dalam hal ini, sebagian besar responden menyatakan bahwa pelayanan kesehatan 24 jam masih terkendala dengan jumlah tenaga medis seperti dokter dan perawat serta peralatan medis yang belum cukup memadai. Seperti terangkum dalam kutipan wawancara berikut,

"Kalo infrastruktur sudah, cuman yang masih kendala disini itu dah, SDM pada bidangbidang yang kurang seperti yang saya bilang tadi, salah satunya mungkin dengan ditambahnya SDM fungsional seperti dokter, perawat, juga sopir beserta ambulan emergency tadi.." (Informan 2).

"Untuk prasarana itu bilanglah untuk ini programnya saya mungkin dari ini ee apa namanya ee apa namanya dari alat alat bilanglah begitu perlu dibantulah lagi sedikit, mungkin dari segi PHmeter" (Informan 11)

Meskipun terdapat beberapa kendala, pelaksanaan kebijakan BLUD ini juga memberikan dampak positif. Sejak diterapkannya kebijakan BLUD, kesejahteraan pegawai di puskesmas perawatan di Kabupaten Gianyar meningkat jika dibandingkan sebelum BLUD. Seperti yang terangkum dalam kutipan wawancara berikut,

"Insentif secara financial sudah sesuai dan sudah lumayan dapatnya dibandingkan dengan puskesmas ini sebelum BLU. Sekarang karena sudah BLU jadinya kita bisa mengelola sendiri dana yang kita miliki untuk berapa persen buat jaspel agar pegawai sejahteralah juga ya..hehe.." (Informan 2).

Dalam pelaksanaannya, hampir sebagian besar responden berpendapat bahwa kebijakan BLUD layak untuk dipertahankan. Alasannya, kebijakan ini membuat puskesmas memiliki 
keleluasaan untuk membuat programprogram yang tepat sasaran sesuai dengan kebutuhan masing-masing puskesmas dan meningkatkan kompetisi antar pemberi layanan kesehatan. Hal ini terungkap dari petikan wawancara berikut,

"BLUD itu kan e..kayak tadi itu kita bisa mengatur keuangan sendiri dan merencanakan sendiri gitu, apa yang kita butuhkan kita rencanakan dari awal, apa yang mau dibeli gitu, kita tau itu biasa diatur." (Informan 3).

"Oo pasti perlu..perlu..sangat perlu itu.. Ya untuk gini, kan peningkatan pelayanan itu bisa di tingkatkan lagi ya masalah kesejahteraan pegawai lebih meningkat lagi." (Informan 4)

D. Penelitian Susilawati (2017) tentang Kinerja Pegawai Dalam Meningkatkan Mutu Pelayanan Kesehatan (Studi Pada Puskesmas Kutalimbaru). Menurut Sudarmanto (2009), indikator kinerja merupakan aspek-aspek yang menjadi tolak ukur dalam menilai kinerja. Kinerja pegawai di puskesmas kutalimbaru dapat dilihat dengan tercapainya berbagai sasaran yang telah ditentukan dan yang dilakukan dengan menggunakan sumbersumber tertentu yang sudah dialokasikan untuk melakukan berbagai kegiatan. Data tersebut akan di analisis dengan menggunakan 4 indikator sebagai berikut:

1. Kualitas

Ketersediaan sarana dan prasarana kesehatan yang ada di puskesmas seudah sesuai dengan standart pelayanan kesehatan yang dimana kepala puskesmas dapat bertanggung jawab atas ketersediaan sarana dan prasarana yang ada di puskesmas kutalimbaru, pihak puskesmas selalu menyediakan sarana dan prasarana yang ada di puskesmas tetapi itu semua tergantung kepada dinas atau atasan yang mempersediakan sarana dan prasarana,tetapi tidak ketersediaan saranan dan prasarana pihak puskesmas selalu bertanggung jawab atas pasien yang emergency dengan memberikan rujukan kepada pasien ke rumah sakit besar yang memberikan fasilitas yang lengkap.
Analisis dari masyarakat tentang kualitas dalam ketersediaan sarana dan prasarana dalam puskesmas kutalimbaru sudah semakin membaik , masyarakat pun merasa puas atas tindakan pegawai puskesmas dalam melakukan tindakan yang bertanggung jawab terhadap pasien yang memang butuh di trasnfer ke rumah sakit besar yang lebih lengkap. Dan mengurus surat rujukan atas pasien yang membutuhkan. Tidak ada keluhan masalah transferan pasien ke rumah sakit umum karena pihak puskesmas menyediakan Ambulance untuk transfort pasien ke rumah sakit yang dituju, karena masyarakat selalu mengeluh masalah transportasi di Kutalimbaru.

2. Kuantitas

Sebagai pegawai puskesmas kutalimbaru sudah mampu bekerja dengan stadart yang ada di puskesmas kutalimbaru, dalam maslah membantu kinerja pegawai puskesmas dapat dilakukan walpun pegawai yang satunya tidak bekerja di bidangnya tersebut, misalnya melakuan posiandu di Kutalimbaru, pegawai yang sudah tidak ada kepentingan di puskesmas dapat membantu bidan yang ada di desa Kutalimbaru untuk memlakukan Pos Pelayanan Terpadu (POSYANDU).

Pihak puskesmas selalu mendukung hal yang semakin membaik dalam melamcarkan tugas-tugas yang telah di tetapkan dan pegawai di puskesmas Kutalimbaru dengan senang hati melakukan saling membantu antara sesama pegawai di puskesmas Kutalimbaru.

\section{Penggunaan Waktu}

Sebagai pegawai puskesmas sudah diwajibakan datang tepat waktu ke puskesmas Kutalimbaru, tetapi ketepatan waktu itu tidak berjalan dengan yang telah di tetapkan, pegawai pskesmas selalu mengelum maslah keterlambatan datang ke puskesmas kutalimbaru masalah transportasi dan jarak antara rumah dan puskesmas, di kampung tersebut dapat di katakan sangan minim maslah jalan yang ada di 
Kutalimbaru, itu penyebab keterlambatan sering terjadi dengan pegawai puskesmas di Kutalimbaru.

\section{Kerja Sama}

Hubungan saling kerja sama antara satu dengan pegawai yang satu lagi sangat baik, menurut responden dengan bapak Haposan Manulang terjamin dalam hal kerja sama antara pegawai di puskesmas Kutalimbaru, dalam hal apapun pegawai puskesmas dapat menjalankan saling kerja sama itu dengan baik.

E. Penelitian Martatilova (dipublikasikan tahun 2020), tentang Pengaruh Kinerja Tenaga Medis Dan Pelayanan Kesehatan Terhadap Sistem Reputasi Layanan Publik Pada Puskesmas Metro. Hasil penelitian tersebut menunjukkan bahwa:

1. Pengaruh Kinerja Tenaga Medis terhadap Sistem Reputasi Layanan Publik

Berdasarkan hasil penelitian menunjukkan bahwa Kinerja Tenaga Medis memiliki pengaruh yang signifikan terhadap Sistem Reputasi Layanan Publik. Pengaruh ini menandakan bawah kinerja yang dimiliki oleh seseorang akan mempengaruhi sistem reputasi layanan publik pada suatu organisasi. Kinerja tenaga medis sendiri memiliki makna sebagai gambaran mengenai tingkat pencapaian pelaksanaan suatu kebijakan dalam mewujudkan sasaran, tujuan, misi dan visi organisasi yang tertuang dalam perencanaan strategis suatu organisasi. Istilah kinerja sering digunakan untuk menyebut prestasi atau tingkat keberhasilan individu maupun kelompok. Kinerja bisa diketahui hanya jika individu atau kelompok tersebut mempunyai kriteria keberhasilan yang telah ditetapkan sebelumnya. Sistem reputasi layanan publik akan menjadi baik apabila kinerja tenaga medis dapat menjalankan tugas yang dibebankan kepadanya secara baik pula, karena sistem reputasi layanan publik dapat pula dijadikan sebagai tolak ukur keberhasilan akan kinerja seorang tenaga medis.
2. Pengaruh Pelayanan Kesehatan terhadap Sistem Reputasi Layanan Publik

Berdasarkan hasil penelitian menunjukkan bahwa Pelayanan Kesehatan memiliki pengaruh yang signifikan terhadap Sistem Reputasi Layanan Publik. Pengaruh ini dapat dimaknai bahwa pelayanan kesehatan yang diberikan oleh seseorang pada Puskesmas akan berdampak pada sistem reputasi layanan publik. Pelayanan kesehatan yang baik tidak hanya di ukur dari sarana maupun prasarana, melainkan bagaimana cara berkomunikasi dan beretika para pegawai terhadap para masyarakat. Apabila pelayanan kesehatan diaplikasikan dengan sepenuh hati secara otomatis akan meningkatkan sistem reputasi layanan publik. Tenaga medis yang berpotensi harus di jaga dan di pertahankan dengan baik serta di manfaatkan dengan baik pula, karena pada dasarnya organisasi tidak hanya ingin mencapai tujuan pada satu waktu, melainkan untuk jangka panjang dan salah satunya adalah pelayanan kesehatan yang baik. Baik buruknya pelayanan kesehatan akan mempengaruhi sistem reputasi layanan publik yang diberikan kepada masyarakat/pasien.

3. Pengaruh Kinerja Tenaga Medis dan Pelayanan Kesehatan terhadap Sistem Reputasi Layanan Publik

Berdasarkan hasil penelitian menunjukkan bahwa Kinerja tenaga medis dan Pelayanan kesehatan memiliki pengaruh secara bersamasama terhadap Sistem reputasi layanan publik. Ditemukannya pengaruh tersebut menggambarkan apabila seseorang tenaga medis yang memiliki kemampuan baik secara kualitas, kuantitas dalam menjalankan pekerjaannya sebagai pelayan masyarakat/pasien dapat meningkatkan sistem reputasi layanan publik secara maksmimal dikarenakan kompetensi yang dimilikinya, selain itu tenaga medis yang berkompeten tersebut secara otomatis dapat memberikan 
pelayanan kesehatan sesuai standar operasional puskesmas dan peraturan perundang-undangan, karena tidak semua tenaga medis itu mampu memahami seluruh standar operasinal puskesmas kecuali tenaga medis yang berkompeten, dengan begitu akan terciptalah suatu sistem reputasi layanan publik yang baik. Jadi, kinerja tenaga medis dan pelayanan kesehatan apabila dipelihara dan dilakukan dengan baik maka akan berdampak pada meningkatnya sistem reputasi layanan publik.

F. Penelitian Widianti (dipublikasikan tahun 2017), tentang Kinerja Pegawai Puskesmas Dalam Pelayanan Kesehatan Di Kecamatan Sangatta Selatan Kabupaten Kutai Timur. Hasil penelitian tersebut menunjukkan :

1. Kinerja pegawai puskesmas dalam pelayanan kesehatan di Kecamatan Sangatta Selatan berdasarkan kualitas belum maksimal, masih adanya pegawai yang ditempatkan tidak sesuai dengan tupoksi karena jumlah pegawai yang banyak. Kurangnya ketelitian pegawai sehigga terjadi kesalahan dalam bekerja dan masih ada pegawai yang mengulur-ngulur waktu dalam mengerjakan tugas.

2. Kinerja pegawai puskesmas dalam pelayanan kesehatan di Kecamatan Sangatta Selatan berdasarkan kuantitas sudah maksimal dapat dlihat dari tabel program kegiatan yang dilaksanakan oleh puskesmas telah mencapai target yang ditentukan. Pegawai selalu mengerjakan pekerjaan mereka dengan baik dan penuh rasa tanggung jawab.

3. Kinerja pegawai puskesmas dalam pelayanan kesehatan di Kecamatan Sangatta Selatan berdasarkan ketepatan waktu sudah cukup maksimal dapat dilihat dari pegawai yang mampu menyeleaikan pekerjaan mereka dengan waktu yang telah ditetapkan sehingga pekerjaan tersebut dapat terselesaikan dengan cepat dan tepat waktu.
4. Kinerja pegawai puskesmas dalam pelayanan kesehatan di Kecamatan Sangatta Selatan berdasarkan efektivitas sudah berjalan dengan maksimal terlihat dari program kegiatan promosi kesehatan yang dilakukan rutin baik di luar gedung maupun dalam gedung, dan pegawai melaksanakan pekerjaan dengan maksimal didukung oleh jumlah tenaga kerja yang ada di puskesmas Sangatta Selatan yang cukup banyak, sehingga dapat memaksimalkan setiap pekerjaan yang diberikan.

5. Faktor penghambat kinerja pegawai puskesmas di Kecamatan Sangatta Selatan adalah kurangnya kesadaran pegawai untuk mentaati ketentuan jam kerja, dan fasilitas medis dan fasilitas pendukung yang ada di puskesmas terbatas, seperti alat bedah, obat-obatan, printer, genset dan komputer. Prasarana seperti lahan parkir yang ada di puskesmas masih kurang nyaman karena jika hujan datang halaman parkir akan becek dan juga genset yang ada di puskesmas tidak kuat saat mati lampu sehingga menghambat pekerjaan pegawai. Dana operasional yang di berikan pemerintah pusat maupun daerah tidak sebanding dengan pengeluaran puskesmas sehingga biaya puskesmas mahal.

G. Penelitian Lestari (dipublikasikan tahun 2018), tentang Upaya Peningkatan Mutu Pelayanan Di Puskesmas Melalui Pendekatan Manajemen Sumberdaya Manusia Kesehatan. Hasil penelitian tersebut menunjukkan bahwa keberadaan puskesmas sangat penting dalam memelihara kesehatan masyarakat. Namun selama ini puskesmas dianggap belum sepenuhnya dapat memenuhi fungsinya dengan baik karena mutu pelayanan di puskesmas masih sering dikeluhkan oleh masyarakat. Berbagai masalah SDMK di puskesmas dapat berpengaruh pada beban kerja dan pada akhirnya mutu pelayaan puskesmas meliputi: masalah ketersediaan tenaga kesehatan termasuk jenis profesi tenaga kesehatan dan sebarannya, serta masalah kompetensi yang meliputi pengetahuan, 
kemampuan atau keterampilan tenaga kesehatan dalam menjalankan tugasnya.

Masalah SDM di puskesmas lainnya yang dapat mempengaruhi mutu pelayanan adalah: belum terintegrasinya sistem perencanaan dan prosedur distribusi tenaga kesehatan; kurangnya kapasitas unit perencanaan SDMK di semua tingkat dalam pendistribusian tenaga kesehatan; kurangnya komunikasi yang baik sehingga ada perbedaan pemahaman, informasi dan pengetahuan tentang distribusi tenaga kesehatan antara unit perencanaan dan penyedia pelayanan kesehatan; kurangnya dukungan dari pemerintah daerah; serta perencanaan yang tidak terintegrasi diberbagai tingkat admisistrasi di pemerintah daerah.

Upaya peningkatan mutu pelayanan puskesmas sudah diatur dalam Peraturan Menkes Nomor 33 Tahun 2015 tentang pedoman penyusunan perencanaan kebutuhan SDMK dan Keputusan Menteri Kesehatan Nomor 81/MENKES/SK///2004 tentang pedoman pemerintah daerah disesuaikan dengan kebutuhan dan perkembangan hukum. Namun demikian pelaksanaannya masih belum maksimal.

H. Penelitian Ainurrahmah (dipublikasikan tahun 2017) tentang Pengaruh Manajemen Pusat Kesehatan Masyarakat terhadap Akses Pelayanan Kesehatan untuk Mewujudkan Mutu Pelayanan Kesehatan. Hasil penelitian tersebut menunjukkan Berdasarkan hasil pembahasan mengenai pengaruh Manajemen Pusat Kesehatan Masyarakat terhadap Akses Pelayanan Kesehatan untuk Mewujudkan Mutu Pelayanan Kesehatan di Puskesmas Kecamatan Tarogong Kidul, dapat ditarik kesimpulan bahwa Manajemen Pusat Kesehatan Masyarakat berpengaruh terhadap Akses Pelayanan Kesehatan untuk Mewujudkan Mutu Pelayanan Kesehatan di Puskesmas Kecamatan Tarogong Kidul. Adapun hasil sub hipotesis dapat ditarik kesimpulan sebagai berikut:

\section{Manajemen Pusat Kesehatan Masyarakat berpengaruh terhadap Akses Pelayanan Kesehatan, yang}

berarti memadai atau tidaknya Akses Pelayanan Kesehatan dipengaruhi oleh Manajemen Pusat Kesehatan Masyarakat.

2. Manajemen Pusat Kesehatan Masyarakat tidak berpengaruh terhadap Mutu Pelayanan Kesehatan, yang berarti terwujudnya Mutu Pelayanan Kesehatan tidak dipengaruhi oleh Manajemen Pusat Kesehatan Masyarakat.

3. Akses Pelayanan Kesehatan berpengaruh terhadap Mutu Pelayanan Kesehatan, yang berarti terwujudnya Mutu Pelayanan Kesehatan dipengaruhi oleh Akses Pelayanan Kesehatan.

Sementara implikasi secara teoritis, referensi teori-teori yang disajikan dan digunakan sebagai dasar penelitian pada prinsipnya dapat berfungsi apabila pendekatan Manajemen Pusat Kesehatan Masyarakat dan Akses Pelayanan Kesehatan untuk mewujudkan Mutu Pelayanan Kesehatan di Puskesmas Kecamatan Tarogong Kidul dilaksanakan dengan baik menurut teori-teori yang ada, namun pada kenyataannya teori-teori tersebut belum diimplementasikan secara utuh.

\section{Pembahasan}

Dari hasil penelitian-penelitian tersebut menunjukkan bahwa semakin baiknya peran pengembangan manajemen kinerja tenaga kesehatan termasuk tenaga adminisrasi kesehatan maka secara signifikan dapat meningkatkan mutu pelayanan kesehatan di puskesmas. Mutu adalah ukuran yang dibuat oleh konsumen terhadap produk atau jasa yang dilihat dari segala dimensi atau karakteristik untuk memenuhi tuntutan kebutuhan, keamanan, dan kenyamanan konsumen. Pelayanan kesehatan yang bermutu adalah pelayanan kesehatan yang dapat memuaskan setiap pemakai jasa pelayanan kesehatan sesuai tingkat kepuasan rata-rata penduduk. Penyelenggaraannya juga harus sesuai dengan standar dan kode etik profesi yang telah ditetapkan. Pasien cenderung memilih atau menetapkan prioritas indikator kualitas pelayanan kesehatan, sebagai dasar untuk memutuskan tingkat 
kepuasannya (Cahyadi, 2007). Baik atau buruknya suatu mutu pelayanan kesehatan maka akan berpengaruh kepada tingkat kepuasan pasien karena pasien akan memberikan tanggapan serta penilaian terhadap mutu pelayanan kesehatan tersebut (Sabarguna, 2008).

Pelayanan adalah suatu kumpulan atau kesatuan yang melakukan kegiatan menguntungkan dan menawarkan suatu kepuasan meskipun hasilnya secara fisik tidak terikat kepada produk (Kotler, 2014). Kesehatan merupakan salah satu kebutuhan dasar masyarakat, maka kesehatan adalah hak bagi setiap warga masyarakat yang dilindungi oleh Undang- Undang Dasar (Daryanto dan Ismanto Setyabudi, 2014). Oleh karena itu, perbaikan pelayanan kesehatan pada dasarnya merupakan suatu investasi sumber daya manusia untuk mencapai masyarakat yang sejahtera (welfare society).

Pelayanan kesehatan (Mubarak dan Nurul Chayatin, 2009) adalah suatu organisasi untuk memelihara dan meningkatkan kesehatan, mencegah dan menyembuhkan penyakit, serta memulihkan kesehatan perseorangan, keluarga, kelompok, dan masyarakat. Peranan pelayanan dalam pelayanan kesehatan masyarakat adalah untuk memberikan pelayanan kepada pasien dengan sebaik mungkin (Dedi Mulyadi, dkk, 2013). Menurut Pohan (2006) pemberi layanan kesehatan harus memahami status kesehatan dan kebutuhan layanan kesehatan masyarakat yang dilayaninya dan mendidik masyarakat tentang layanan kesehatan dasar dan melibatkan masyarakat dalam menentukan bagaimana cara efektif menyelenggarakan layanan kesehatan.

Di dalam peningkatan mutu layanan kesehatan tentunya uga tidak lepas dari bagaimana baiknya manajemen kinerja. Layanan kesehatan juga merupakan sebuah organisasi yang dapat disebut juga organisasi kesehatan. Suatu organisasi dibentuk untuk mencapai tujuan organisasi. Pencapaian tujuan organisasi menunjukkan hasil kerja/prestasi organsisasi dan menunjukkan kinerja organisasi. Hasil kerja organisasi diperoleh dari serangkaian aktivitas yang dijalankan. Aktivitas tersebut dapat berupa pengelolaan sumberdaya organisasi maupun proses pelaksanaan kerja yang diperlukan untuk mencapai tujuan organisasi. Untuk menjamin agar aktivitas tersebut dapat mencapai hasil yang diharapkan, diperlukan upaya manajemen dalam pelaksanaan aktivitasnya.

Dengan demikian, hakikat manajemen kinerja adalah bagaimana mengelola seluruh kegiatan organisasi untuk mencapai tujuan organisasi yang telah ditetapkan sebelumnya. Manajemen kinerja bukannya memberi manfaat kepada organisasi saja tetapi juga kepada manajer dan individu. Bagi organisasi, manfaat manajemen kinerja adalah menyesuaikan tujuan organisasi dengan tujuan tim dan individu, memperbaiki kinerja, memotivasi pekerja, meningkatkan komitmen, mendukung nilai-nilai inti, memperbaiki proses pelatihan dan pengembangan, meningkatkan dasar ketrampilan, mengusahakan perbaikan dan pengembangan berkelanjutan, mengusahakan basis perencanaan karier, membantu menahan pekerja terampil agar tidak pindah, mendukung inisiatif kualitas total dan pelayanan pelanggan, mendukung program perubahan budaya.

Menurut Costello (1994) manajemen kinerja mendukung tujuan menyeluruh organisasi dengan mengaitkan pekerjaan dari setiap pekerja dan manajer pada misi keseluruhan dari unit kerjanya. Seberapa baik kita mengelola kinerja bawahan akan secara langsung mempengaruhi tidak saja kinerja masing-masing pekerja secara individu dan unit kerjanya, tetapi juga kinerja seluruh organisasi.

Apabila pekerja telah memahami tentang apa yang diharapkan dari mereka dan mendapat dukungan yang diperlukan untuk memberikan kontribusi pada organisasi secara efisien dan produktif, pemahaman akan tujuan , harga diri dan motivasinya akan meningkat. Dengan demikian, manajemen kinerja memerlukan kerja sama, saling pengertian dan komunikasi secara terbuka antara atasan dan bawahan.

Manajemen kinerja adalah suatu proses yang dirancang untuk meningkatkan kinerja organisasi, kelompok, dan individu yang digerakkan oleh para manajer. Manajemen kinerja mencakup pengkajian ulang terhadap kinerja secara berkesinambungan dan dilakukan secara bersama berdasarkan kesepakatan mengenai sasaran, keahlian, kompetensi, rencana kerja dan pengembangan, serta pengimplementasian 
rencana peningkatan dan pengembangan lebih lanjut.

\section{Kesimpulan}

Semakin baiknya peran pengembangan manajemen kinerja tenaga kesehatan termasuk tenaga adminisrasi kesehatan maka secara signifikan dapat meningkatkan mutu pelayanan kesehatan di puskesmas.

\section{Saran}

Agar lebih dipersiapkan terkait dengan ketersediaan literatur seperti buku, artikel, jurnal dan literatur lainnya sehingga dalam proses pengerjaan studi/penelitian kepustakaan dapat membahas teori secara mendalam. Perlunya persiapan kondisi fisik serta mental karena dalam Penelitian/studi kepustakaan lebih banyak menghabiskan waktu dengan duduk dan menghadap layar serta buku yang membuat kondisi mata harus dipersiapkan dan dijaga. Perlunya kelanjutan penelitian/studi kepustakaan dengan sumbersumber atau literatur yang lebih banyak lagi dan bahkan dari hasil penelitian-penelitian yang bukan hanya secara nasional, akan tetapi perlu dikembangkan ke skala internasional sehingga penelitian/studi kepustakaan ini lebih baik lagi.

\section{Ucapan Terima Kasih}

Terima kasih disampaikan kepada Ketua Stikes Pamenang, Suryono, S.Kep.Ns., MMRS atas motivasi dan kesempatan yang diberikan; Ketua PPPM Stikes Pamenang, Dr. Zauhani KH, SKM., M.Kes. atas dukungan, motivasi dan arahannya; Reviewer Jurnal Ilmiah Pamenang (JIP); Editor Jurnal Ilmiah Pamenang (JIP); Rekan-rekan dosen Stikes Pamenang umumnya dan rekan-rekan dosen prodi S1 Administrasi Kesehatan khususnya; Serta semua pihak yang turut mendukung dalam penyelesaian studi kepustakaan ini.

\section{Daftar Pustaka}

Ainurrahmah, Yusni. (2017). Pengaruh Manajemen Pusat Kesehatan Masyarakat terhadap Akses Pelayanan Kesehatan untuk Mewujudkan Mutu Pelayanan Kesehatan. Jurnal Publik. Vol. 11; No. 02; 2017; 239256. P-ISSN: 1412-7083. E-ISSN: 25799266.

Aisyah, Yekti, dkk. (2016). Penilaian Kinerja Pegawai Puskesmas Rowosari. Administrasi Publik. FISIP. Universitas Diponegoro. Semarang.
Arisandy, Winda. (2015). Strategi Dinas Kesehatan dalam Meningkatkan Kualitas Pelayanan Kesehatan melalui Metode CRC (Citizen Report Card). Jurnal Kebijakan dan Manajemen Publik. Volume 3, Nomor 2, Mei-Agustus 2015. ISSN 2303 - 341X. Universitas Airlangga. Surabaya.

Harahap, Nida P. (2019). Sumber Daya Manusia Kesehatan (Kajian Sektor Kesehatan). Cetakan pertama: April 2019. ISBN: 978623-93153-2-0. Direktorat Kesehatan dan Gizi Masyarakat. Kedeputian Pembangunan Manusia, Masyarakat dan Kebudayaan. Kementerian PPN/Bappenas. Jakarta Pusat.

Husaini, Abdullah. (2017). Peranan Manajemen Sumberdaya Manusia Dalam Organisasi. Jurnal Warta Edisi : 51 Januari 2017 | ISSN : 1829 - 7463. Universitas Jabal Ghafur. Takengon.

Indrayathi, Putu Ayu, dkk. (2014). Mutu Pelayanan Puskesmas Perawatan yang Berstatus Badan Layanan Umum Daerah. Jurnal Kesehatan Masyarakat Nasional. Volume 9 No.2 November 2014. ISSN 1907-7505. Universitas Udayana. Bali.

Lestari, Puji, Tri Rini. (2016). Analysis Of Availability Health Personnel In The Health Center Of Mamuju In West Sulawesi. Kajian Vol. 21 No. 1 Maret 2016 hal. 75 88. Pusat Penelitian Badan Keahlian DPR RI, Nusantara II, Lantai 2, DPR RI, Jl. Jend. Gatot Subroto, Senayan, Jakarta 10270, Indonesia.

Lestari, Puji, Tri Rini. (2018). Upaya Peningkatan Mutu Pelayanan Di Puskesmas Melalui Pendekatan Manajemen Sumberdaya Manusia Kesehatan. Kajian Vol. 23 No. 3 September 2018 hal. 157 - 174. Pusat Penelitian Badan Keahlian DPR RI, Nusantara I, Lantai 2, DPR RI Jl. Jend. Gatot Subroto, Senayan, Jakarta 10270, Indonesia.

Martatilova, Andhina. (2020). Pengaruh Kinerja Tenaga Medis Dan Pelayanan Kesehatan Terhadap Sistem Reputasi Layanan Publik Pada Puskesmas Metro. Jurnal Manajemen. Vol. 14 No. 1 April 2020. ISSN Cetak 1978-6573. ISSN Online 2477-300X. Universitas Muhammadiyah Metro.

Menkes RI. (2004). Kebijakan Dasar Pusat Kesehatan Masyarakat. Keputusan Menteri Kesehatan Republik Indonesia Nomor 128/MENKES/SK/II/2004.

Menkes RI. (2009). Pedoman Penilaian Kinerja Sumber Daya Manusia Kesehatan di Puskesmas. Keputusan Menteri Kesehatan Republik Indonesia Nomor 857/MENKES/SK/IX/2009.

Mustofa, Amirul, dkk. (2020). Administrasi Pelayanan Kesehatan Masyarakat. Cetakan 
Pertama. CV. Jakad Media Publishing. Surabaya.

Saputra, Mitriadi. (2016). Analisis Kinerja Tenaga Medis Puskesmas Kecamatan Kampar Utara Kabupaten Kampar. JOM FISIP Vol. 3 No. 2 Oktober 2016. Universitas Riau.

Sundari. (2019). Manajemen Kinerja. Universitas Pertahanan. Bogor.

Susilawati. (2017). Kinerja Pegawai Dalam Meningkatkan Mutu Pelayanan Kesehatan (Studi Pada Puskesmas Kutalimbaru). Skripsi. FIA. USU.

Tarumaselej, Lita Astrid. (2020). Pengaruh Manajemen Puskesmas Terhadap Mutu Pelayanan Puskesmas Di Kota Ambon. Tesis. Fakultas Kesehatan Masyarakat. Universitas Hasanuddin. Makassar.

Widianti, Rosie Fitria, dkk. (2017). Kinerja Pegawai Puskesmas Dalam Pelayanan Kesehatan Di Kecamatan Sangatta Selatan Kabupaten Kutai Timur. eJournal Ilmu Pemerintahan, 2017, 6 (1): 185-198. ISSN 2477-2458 (online). ISSN 2477-2631 (cetak). ejournal.ip.fisip-unmul.ac.id 